\title{
Identification and Origin of Xanthomonas campestris pv. campestris Races and Related Pathovars
}

\author{
J. G. Vicente, J. Conway, S. J. Roberts, and J. D. Taylor
}

Horticulture Research International, Wellesbourne, Warwick CV35 9EF, U.K.

Accepted for publication 19 January 2001.

\begin{abstract}
Vicente, J. G., Conway, J., Roberts, S. J., and Taylor, J. D. 2001. Identification and origin of Xanthomonas campestris pv. campestris races and related pathovars. Phytopathology 91:492-499.

One hundred sixty-four isolates of Xanthomonas campestris pv. campestris and other $X$. campestris pathovars known to infect cruciferous hosts (X. campestris pvs. aberrans, raphani, armoraciae, and incanae) were inoculated onto a differential series of Brassica spp. to determine both pathogenicity to brassicas and race. Of these, 144 isolates were identified as $X$. campestris pv. campestris and grouped into six races, with races $1(62 \%)$ and $4(32 \%)$ being predominant. Other races were rare. The remaining 20 isolates from brassicas and other cruciferous hosts were either nonpathogenic or very weakly pathogenic on the dif-
\end{abstract}

ABSTRACT ferential series and could not be race-typed. Five of these isolates, from the ornamental crucifers wallflower (Cheiranthus cheiri), stock (Matthiola incana) and candytuft (Iberis sp.), showed clear evidence of pathovar-like specificity to the hosts of origin. A gene-for-gene model based on the interaction of four avirulence genes in X. campestris pv. campestris races and four matching resistance genes in the differential hosts is proposed. Knowledge of the race structure and worldwide distribution of races is fundamental to the search for sources of resistance and for the establishment of successful resistance breeding programs.

Additional keywords: black rot of crucifers, disease resistance, pathogen variants.
Black rot of crucifers caused by Xanthomonas campestris pv. campestris (Pammel) Dowson is possibly the most important disease of crucifers worldwide (35). Economically, the most important host of $X$. campestris pv. campestris is Brassica oleracea (including cabbage, cauliflower, broccoli, Brussels sprouts, and kale), but it also attacks other Brassica spp. and is reported on a number of cruciferous crops, weeds, and ornamentals (3).

The genus Xanthomonas has a wide host range extending over 66 genera of nine monocotyledonous families and 160 genera of 49 dicotyledonous families (21). The species $X$. campestris (Pammel) Dowson was formerly divided into 123 pathovars according to host specificity (8). However, recent reclassification of the genus based on DNA-DNA hybridization (31) proposed that the species $X$. campestris should be restricted to $X$. campestris pv. campestris and five pathovars that cause disease in cruciferous plants (X. campestris pvs. aberrans (Knösel) Dye, armoraciae (McCulloch) Dye, barbareae (Burkholder) Dye, incanae (Kendrick \& Baker) Dye, and raphani (White) Dye. These related pathovars have received little attention, and there have been no extensive comparative studies of their host range. Alvarez et al. (1) and Vauterin et al. (31) expressed some doubt of the distinction of some of these pathovars from $X$. campestris $\mathrm{pv}$. campestris.

In addition to distinctions based on host range (pathovars), several Xanthomonas spp. and pathovars have been further differentiated into races based on their interaction with differential cultivars. Thus, more than 20 races were proposed for $X$. oryzae (24), 17 races for $X$. campestris pv. malvacearum $(4,12)$, and 8 races for $X$. campestris pv. phaseoli (25). For $X$. campestris pv. vesicatoria, eight races were defined on the basis of their inter-

Corresponding author: J. G. Vicente; E-mail address: joana.vicente@hri.ac.uk

Publication no. P-2001-0316-02R

(C) 2001 The American Phytopathological Society actions with pepper cultivars and three races with tomato cultivars (16). Kamoun et al. (18) separated the isolates of $X$. campestris pv. campestris into five different races ( 0 to 4$)$ based on the response of certain cultivars of turnip ( $B$. rapa) and a cultivar of mustard (B. juncea). Other studies indicated that some accessions of $B$. napus and $B$. oleracea have differential reactions to $X$. campestris pv. campestris isolates (15). Vicente et al. (33) suggested that race 1 could be subdivided into three races (tentatively designated $1 \mathrm{a}, 1 \mathrm{~b}$, and $1 \mathrm{c}$ ) on the basis of their reaction on several accessions of $B$. oleracea and one of $B$. carinata. Similarly, Ignatov et al. (14) separated a group of isolates formerly included in race 1 into two races ( 1 and 5) on the basis of their reaction on two B. oleracea accessions.

With the exception of Kamoun et al. (18) and the few recent studies mentioned, all previous studies failed to recognize the existence of races of $X$. campestris pv. campestris. Where variation between $X$. campestris pv. campestris isolates was recognized, it was generally considered to represent merely a difference in aggressiveness. Most studies of resistance to $X$. campestris pv. campestris have been concerned with $B$. oleracea, identifying only a few potentially useful sources $(11,36)$. However, resistance has been found in other Brassica spp. $(2,10,34)$. One of the problems in determining the potential usefulness of resistance sources is the misidentification of Brassica spp. Flow cytometry and cytology results showed that several accessions were wrongly classified (J. D. Taylor, J. Conway, S. J. Roberts, and J. G. Vicente, unpublished data).

This paper presents information on the occurrence of pathogenic variants (races) among isolates of $X$. campestris pv. campestris and related pathovars from the United Kingdom and from different geographical regions of the world. An improved differential series for the determination of races of $X$. campestris pv. campestris is described. A gene-for-gene model is proposed to explain the interaction of races and differential cultivars. The implications of this model for resistance breeding strategies in $B$. oleracea are discussed. 


\section{MATERIALS AND METHODS}

Bacterial isolates. Isolates were obtained in the United Kingdom from field outbreaks of black rot and from commercial seed lots, as part of a number of studies done at Horticulture Research International, Wellesbourne (HRI-W). Isolates were initially considered to be $X$. campestris pv. campestris on the basis of colony characteristics on King's medium B (20) or yeast dextrose chalk agar (YDC) and agglutination tests with antiserum conjugated to Staphylococcus aureus (22). In addition, representative isolates of $X$. campestris pv. campestris and related $X$. campestris pathovars from cruciferous hosts $(X$. campestris pvs. aberrans, armoraciae, incanae, and raphani) were obtained from researchers in different countries and from the National Collection of Plant Pathogenic Bacteria (NCPPB). A total of 164 isolates from Brassica spp. and other cruciferous species were included in this study (Table 1). Fifteen isolates representative of Xanthomonas spp. and pathovars from noncruciferous hosts also were included for comparative purposes. For long-term storage, bacterial growth was suspended in a liquid medium containing $8 \mathrm{~g} /$ liter of nutrient broth (Difco Laboratories, Detroit) and $150 \mathrm{ml} /$ liter of glycerol and maintained on glass beads at $-76^{\circ} \mathrm{C}(9)$.

Plant material. The cultivars and accessions used in this study are listed in Table 2. Initially, 12 accessions of Brassica spp., including four differentials previously described by Kamoun et al. (18) (Table 3) and other susceptible or differential accessions, were used to characterize the isolates. An improved differential series, including a selection of Brassica differentials used previously and three new differentials, was used to further characterize representative isolates of the emerging races (Table 2). At least two plants of each accession were inoculated per isolate. Where accessions were known to lack uniformity (e.g., cv. Seven Top Turnip), at least three plants were used.

The pathogenicity of isolates representative of $X$. campestris pvs. aberrans, armoraciae, incanae, and raphani, together with the "race type strains" of the six X. campestris pv. campestris races, was further tested on two or three plants of Savoy cabbage (B. oleracea) cv. Wirosa F1; radish (Raphanus sativus) cvs. Mino Early, French Breakfast, and Mantanghong; wallflower (Cheiranthus cheiri) cvs. Orange bedder and Primrose bedder; stock (Matthiola incana) cv. Brompton stock mixed; and candytuft (Iberis sp.) cvs. Hyacinth flowered and Flash mixed. Single plants of horseradish (Armoracia rusticana) were inoculated with selected isolates. Pathogenicity of isolates of representative Xanthomonas spp. and pathovars from noncruciferous hosts was tested on plants of Savoy cabbage (B. oleracea) cv. Wirosa F1 (two plants per isolate).

Plants were raised from seed sown in 9-cm plastic pots filled with Levington M2 compost (The Scotts Company Ltd., Ipswich, UK). Pots were placed in a greenhouse with a minimum temperature of $20 / 15^{\circ} \mathrm{C}$ (day/night), venting at $22 / 17^{\circ} \mathrm{C}$ (day and night) and with supplementary lighting from October to March to give $16 \mathrm{~h}$ days.

Inoculations. Plants were inoculated approximately 4 weeks after sowing. Isolates were grown on King's medium B at $30^{\circ} \mathrm{C}$ for $48 \mathrm{~h}$ before inoculation. Bacterial growth was scraped from the plates and suspended in $10 \mathrm{ml}$ of sterile tap water or saline solution $(0.85 \% \mathrm{NaCl})$ to produce a turbid suspension $\left(10^{8}\right.$ to $10^{9}$ $\mathrm{CFU} / \mathrm{ml})$. Leaves were inoculated by clipping secondary veins, near the margins, with mouse tooth forceps (15). The teeth of the forceps were wrapped in cotton wool to hold inoculum and dipped into the bacterial suspension. Approximately 10 to 12 points of inoculation were made per leaf, and the three youngest leaves on each plant were inoculated. The number of infected points per leaf and the severity of symptoms were assessed 2 and 3 weeks after inoculation. They were rated on a scale of 0 to 3 based on the relative size of the largest lesion on the leaf: 0, no symptoms; 1 , slight necrosis or chlorosis surrounding the infection point; 2 , typical V-shaped yellow or necrotic lesion with blackened veins with a lesion size of less than $1 \mathrm{~cm}^{2}$, and 3, typical V-shaped lesion with a size of more than $1 \mathrm{~cm}^{2}$. Several re-isolations were performed to determine the presence or absence of bacteria in association with disease symptoms in radish, horseradish, and ornamental crucifers.

\section{RESULTS}

Pathogenicity of isolates. One hundred forty-four isolates from cruciferous hosts (Table 1) were pathogenic on Savoy cabbage cv. Wirosa F1 and one or more accessions of the Brassica spp. tested, giving symptoms generally typical of the disease: V-shaped yellow lesions with black veins and usually with necrotic centers. These isolates were considered to be $X$. campestris pv. campestris. Twenty other isolates, including representatives of other pathovars of cruciferous crops (Table 1), were either nonpathogenic or very weakly pathogenic on all the Brassica accessions tested. Fifteen isolates representative of Xanthomonas spp. and pathovars from noncruciferous hosts (Table 1) failed to produce symptoms after inoculations on cv. Wirosa F1 plants.

Race determination. The reaction of the differential cultivars described by Kamoun et al. (18) (Table 3) was used for the initial separation of $X$. campestris pv. campestris isolates into races. Isolates corresponding to Kamoun's races $0,1,2$, and 4 were identified among those tested, but isolates showing the pattern of reaction of Kamoun's race 3 were not found. In addition, a comparative test of Kamoun's race 3 isolate (HRI 6312) and the "race 4 type strain" (HRI 1279A) was made in paired inoculations on 50 plants of B. rapa cv. Seven Top Turnip. Plants were either susceptible to both isolates ( 7 plants) or resistant to both isolates (43 plants). For this reason, race 3 as defined by Kamoun et al. (18) was withdrawn from our model.

The additional differentials presented in Table 2 were obtained by a process of trial and error as new cultivars or lines with differential responses were identified as part of a screening to identify sources of resistance (Taylor et al., unpublished data). We have identified several accessions of B. oleracea, e.g., cv. Miracle $\mathrm{F} 1$ and a doubled haploid line derived from cv. Böhmerwaldkohl, with resistance to some isolates of race 1 . Based on this reaction, race 1 was separated into two races: race 1 (compatible interaction with cv. Miracle F1) and new race 3 (incompatible interaction with cv. Miracle F1). Similarly, a selection from the $B$. carinata accession PI 199947 was susceptible to isolates of race 0 and some isolates of race 1. Based on this reaction, a new race (race 5, compatible interaction with PI 199947) was added to the model. Finally, race 0 was renumbered as race 6 in the new model.

B. rapa cvs. Just Right Turnip and Tokyo Cross Turnip were both uniformly resistant to race 4; Just Right Turnip was selected as the primary race 4 differential. Accessions of $B$. napus cvs. English Giant and Cobra and $B$. rapa cvs. Seven Top Turnip and Green Globe Turnip gave variable reactions when inoculated with several isolates especially from race $4 ; B$. napus accession CrGC5 showed variable levels of partial resistance to isolates of this race (Table 2). Of these differentials, only cv. Seven Top Turnip had to be maintained in the new differential series to allow the separation of race 2; a minimum of three plants per isolate was used to allow for variability. The line 14R, a selection from cv. Cobra, was uniformly resistant to race 4 isolates; this line was included as an additional race 4 differential. B. juncea cv. Florida Broad Leaf Mustard was fully susceptible only to isolates of race 6 , and on this basis was included as a differential. This accession also showed a partially resistant response when inoculated with isolates of race 5. The cabbage accession PI 436606 gave variable reactions when inoculated with isolates of various races (including races 1,4 , and 6) and on this basis was rejected as a potential differential. The broccoli cv. Marathon F1 was susceptible or partially susceptible to isolates of all races, and cv. Wirosa F1 and 
TABLE 1. Source and origin of 164 Xanthomonas campestris isolates from cruciferous hosts and 15 Xanthomonas isolates from noncruciferous hosts

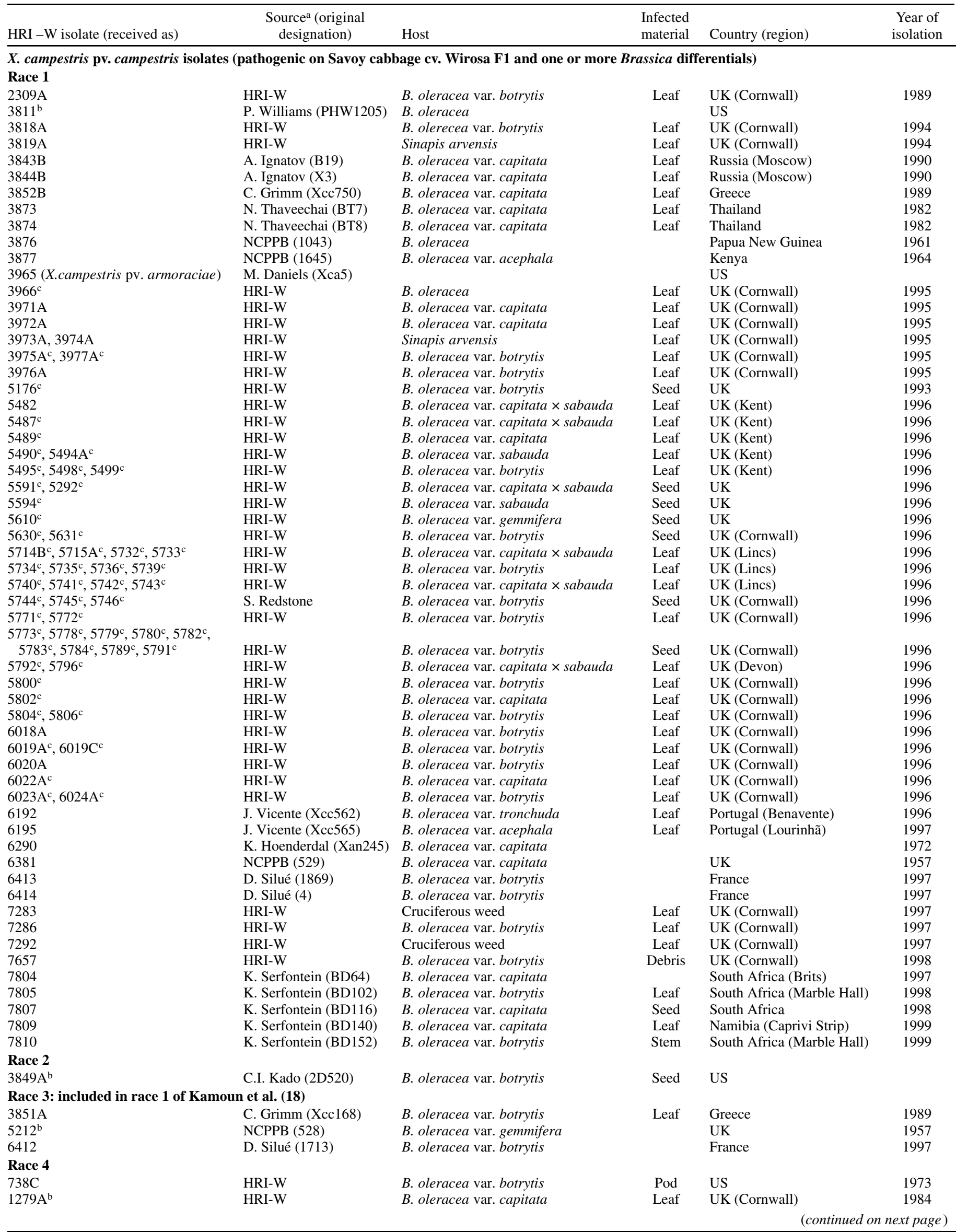

${ }^{\text {a }}$ HRI-W, Horticulture Research International, Wellesbourne, UK; NCPPB, National Collection of Plant Pathogenic Bacteria, Sand Hutton, UK.

b Proposed race type strains.

${ }^{\mathrm{c}}$ Isolates not tested on the three new differentials (Miracle F1, PI 199947 and Cobra 14R); these isolates are most probably race 1. 


\begin{tabular}{|c|c|c|c|c|c|}
\hline HRI -W isolate(received as) & $\begin{array}{c}\text { Source }^{\mathrm{a}} \text { (original } \\
\text { designation) }\end{array}$ & Host & $\begin{array}{l}\text { Infected } \\
\text { material }\end{array}$ & Country (region) & $\begin{array}{l}\text { Year of } \\
\text { isolation }\end{array}$ \\
\hline $2243 \mathrm{~A}$ & HRI-W & Brassica $\mathrm{sp}$ & & Kenya & 1988 \\
\hline $3820 \mathrm{~A}, 3830 \mathrm{~A}$ & HRI-W & B. oleracea var. botrytis & Leaf & UK (Cornwall) & 1994 \\
\hline $3831 \mathrm{~A}$ & HRI-W & B. oleracea var. botrytis & Leaf & UK (Cornwall) & 1994 \\
\hline $3832 \mathrm{~A}, 3833 \mathrm{~A}$ & HRI-W & B. oleracea var. botrytis & Leaf & UK (Cornwall) & 1994 \\
\hline $3834 \mathrm{~A}, 3835 \mathrm{~A}$ & HRI-W & B. oleracea var. botrytis & Leaf & UK (Cornwall) & 1994 \\
\hline $3836 \mathrm{E}$ & HRI-W & B. oleracea var. botrytis & Leaf & UK (Cornwall) & 1994 \\
\hline 3964 & M. Daniels (147) & & & Brazil & \\
\hline 5190 & HRI-W & B. oleracea var. botrytis & Seed & UK & 1993 \\
\hline 5485 & HRI-W & B. oleracea var. capitata $\times$ sabauda & Leaf & UK (Kent) & 1995 \\
\hline 5486 & HRI-W & B. olerecea var. gemmifera & Leaf & UK (Kent) & 1996 \\
\hline \multicolumn{6}{|l|}{$5582,5585,5586,5587$} \\
\hline 5588,5589 & HRI-W & B. oleracea var. botrytis & Seed & UK & 1996 \\
\hline 5651,5655 & HRI-W & B. oleracea var. botrytis & Leaf & UK (Cornwall) & 1996 \\
\hline 5659,5661 & HRI-W & B. oleracea var. botrytis & Leaf & UK (Devon) & 1996 \\
\hline 5737 & HRI-W & B. oleracea var. botrytis & Leaf & UK (Lincs) & 1996 \\
\hline \multicolumn{6}{|l|}{ 5808, 5811A, 5811B, 5812, 5814, } \\
\hline 5816,5819 & HRI-W & B. oleracea var. botrytis & Leaf & UK (Cornwall) & 1996 \\
\hline 6189 & J. Vicente (Xcc559) & B. oleracea var. italica & Leaf & Portugal (Muge) & 1996 \\
\hline 6194 & J. Vicente (Xcc564) & B. oleracea var. capitata & Leaf & Portugal (Lourinhã) & 1997 \\
\hline 6309A & HRI-W & B. oleracea & Leaf & Spain & 1998 \\
\hline 6312 & C.I. Kado (2D513R) & B. oleracea var. botrytis & Leaf & US (California) & \\
\hline 6366 & M. Scortichini (053) & B. oleracea var. gongylodes & Leaf & Italy (Latina) & 1994 \\
\hline 6367 & M. Scortichini (352) & B. oleracea var. botrytis & Leaf & Italy (Latina) & 1991 \\
\hline 6368 & V. Catara (62.4) & B. oleracea var. gongylodes & Leaf & Italy & 1996 \\
\hline 6369 & V. Catara (65.3) & B. oleracea var. italica & Leaf & Italy & 1996 \\
\hline 7290 & HRI-W & B. oleracea var. botrytis & Leaf & UK (Cornwall) & 1997 \\
\hline 7758 & HRI-W & B. oleracea var. tronchuda & Leaf & Brazil (Minas Gerais) & 1999 \\
\hline 7803 & K. Serfontein (BD63) & B. oleracea var. capitata & & South Africa (Brits) & 1997 \\
\hline 7806 & K. Serfontein (BD105) & B. oleracea var. capitata & Leaf & South Africa (Northam) & 1998 \\
\hline 7808 & K. Serfontein (BD128) & B. oleracea var. capitata & Stem & South Africa & 1999 \\
\hline \multicolumn{6}{|c|}{ Race 5: included in race 1 of Kamoun et al. (18) } \\
\hline $3880^{\mathrm{b}}($ X. campestris pv. aberrans $)$ & NCPPB (2986) & B. oleracea var. capitata & & Australia & 1975 \\
\hline 3883 (X. campestris pv. raphani) & NCPPB (1946) & Raphanus sativus & & US & 1966 \\
\hline 6382 & NCPPB (1711) & B. rapa & & Canada & 1953 \\
\hline \multicolumn{6}{|c|}{ Race 6: race 0 of Kamoun et al. (18) } \\
\hline $6181^{\mathrm{c}}$ & J. Vicente (Xcc551) & B. rapa & Leaf & Portugal (Sardoal) & 1996 \\
\hline 6185 & J. Vicente (Xcc555) & B. rapa & Leaf & Portugal (Castelo Branco) & 1996 \\
\hline \multicolumn{6}{|c|}{ Wake or nonpathogenic on Savoy cv. Wirosa F1 and on Brassica differentials } \\
\hline 3777A & HRI-W & Cheiranthus cheiri & Leaf & UK & 1994 \\
\hline $3836 \mathrm{C}$ & HRI-W & B. oleracea var. botrytis & Leaf & UK (Cornwall) & 1994 \\
\hline 3842B & A. Ignatov (PA1) & B. oleracea var. capitata & & Russia (Moscow) & 1993 \\
\hline 3845B & A. Ignatov (13-56) & B. oleracea var. capitata & & Germany & 1988 \\
\hline 3846B & A. Ignatov (Xc8181) & B. oleracea var. capitata & & Russia (St. Petersburg) & 1990 \\
\hline 3875 & A. Franken (Xcc102) & B. oleracea var. capitata & & & \\
\hline 3961 & M. Daniels (8004) & B. oleracea var. botrytis & & UK & 1958 \\
\hline 3962 & M. Daniels (8417) & & & UK & \\
\hline 3963 & M. Daniels (8480) & & & UK & \\
\hline 5219 & NCPPB (2517) & Cheiranthus cheri & & UK & 1973 \\
\hline $5713 \mathrm{~A}$ & HRI-W & B. oleracea var. capitata $\times$ sabauda & Leaf & UK (Lincs) & 1996 \\
\hline 5790 & S. Redstone (19-1-1.1) & B. oleracea var. botrytis & & UK (Cornwall) & 1996 \\
\hline 6374 (X. campestris pv. aberrans) & NCPPB $(875)$ & B. oleracea var. botrytis & & Germany & 1958 \\
\hline 6375 (X. campestris pv. armoraciae) & NCPPB (347) & Iberis $\mathrm{sp}$. & & Tanzania & 1954 \\
\hline 6376 (X. campestris pv. armoraciae) & NCPPB (1930) & Amoracia rusticana & & & 1939 \\
\hline 6377 (X. campestris pv. incanae) & NCPPB (937) & Matthiola sp. & & US & 1950 \\
\hline 6378 (X. campestris pv. incanae) & NCPPB (1934) & Matthiola incana & & US & 1949 \\
\hline 6379 & NCPPB (45) & B. napus & & UK & 1941 \\
\hline 6380 & NCPPB (404) & B. napobrassica & & New Zealand & 1953 \\
\hline 6383 & NCPPB (2857) & B. napus & & UK & 1975 \\
\hline \multicolumn{6}{|c|}{ Xanthomonas isolates from noncruciferous hosts (not pathogenic on Savoy cabbage cv. Wirosa F1) } \\
\hline $64 \mathrm{~A}$ & HRI-W & Lobelia & Leaf & UK & 1967 \\
\hline 1944E (X. campestris pv. phaseoli) & HRI-W & Phaseolus vulgaris & & Rwanda & 1987 \\
\hline 2134B & HRI-W & Allium cepa & Leaf & Barbados & 1988 \\
\hline $2376 \mathrm{~A}$ & HRI-W & Allium cepa & Leaf & Barbados & 1989 \\
\hline 3243A (X. campestris pv. vitians) & HRI-W & Latuca sativa & Leaf & Portugal & 1992 \\
\hline 3342A (X. campestris pv. phaseoli) & A.F. Opio (1002) & Phaseolus vulgaris & & Uganda & 1993 \\
\hline 3416A (X. campestris pv. phaseoli) & HRI-W & Phaseolus vulgaris & & Tanzania & 1993 \\
\hline 3872E (X. campestris pv. vitians) & HRI-W & Latuca sativa & Leaf & Kenya & 1995 \\
\hline 5232 (X. campestris pv. malvacearum) & NCPPB $633^{b}$ & Gossypium sp. & & Sudan & 1958 \\
\hline 5235 (X. campestris pv. vesicatoria) & NCPPB $422^{b}$ & Lycopersicum esculentum & & New Zealand & 1955 \\
\hline 5616 (X. campestris pv. pelargonii) & HRI-W & Pelargonium & Leaf & UK & 1996 \\
\hline $5852(X$. hortorum pv. hedera) & HRI-W & Hedera hibernica & Leaf & UK & 1997 \\
\hline $6013(X$. fragariae $)$ & M. Scortichini (030) & Fragaria $\times$ ananassa & Leaf & Italy (Latina) & 1993 \\
\hline 6014 (X. campestris pv. pruni) & M. Scortichini (006) & Prunus salicina & Leaf & Italy (Latina) & 1991 \\
\hline 6301 (X. campestris pv. carotae $)$ & NCPPB (3440) & Daucus carota & & Brazil & 1985 \\
\hline
\end{tabular}


B. napus cv. Capricorn were susceptible to all the races. Cultivar Wirosa F1 was preferred as the "susceptible control" (susceptible to all isolates and races).

Occurrence and distribution of races. According to the classification of Kamoun et al. (18) (Table 3), isolates from the United Kingdom belonged to race $1(70 \%)$ and race $4(30 \%)$ (Table 4$)$. All isolates of the original race 1 that were tested on the new differential series were confirmed as the new race 1 with the exception of the NCPPB type strain (NCPPB 528; HRI 5212), which was reclassified as the new race 3 . Due to the very low frequency of race 3 , UK isolates that were not fully tested on the new differential series were most likely to conform to the new race 1 designation (Table 4). Races 2, 5, and 6 were not found among any UK isolates.

Race 1 of Kamoun et al. (18) was also predominant among isolates outside the United Kingdom (57\%), followed by race 4 $(36 \%)$ (Table 5). All original race 1 isolates from non-UK sources were tested on the new differential series. These isolates were mainly confirmed as the new race 1, but two European isolates (from Greece and France) were identified as new race 3, and three non-European isolates (from Australia, Canada, and the United States) were identified as new race 5. Overall, races 2, 3, 5, and 6 were rare among the non-UK isolates tested.

There appeared to be no relationship between race and geographical origin of the isolates, but some evidence for a relationship between race and host of origin was found. Race 1, 2, 3, and 4 isolates were all from different $B$. oleracea crops or cruciferous weeds growing in association with $B$. oleracea crops (Table 1). However, four of the five isolates that comprised races 5 and 6 were from turnip (three isolates) or radish (one isolate, received as $X$. campestris pv. raphani). The single isolate of race 5 from $B$. oleracea was received as $X$. campestris pv. aberrans. Moreover, the isolates of races 5 and 6 often produced lesions with extensive dark necrosis and only limited chlorosis (blight-like symptoms) on susceptible hosts such as cv. Wirosa F1.

X. campestris pathovars. The results of inoculations of other cruciferous species including known hosts of related pathovars are presented in Table 6. Representative isolates of the six X. campestris pv. campestris races were pathogenic on radish, but not on horseradish. There was no evidence of good compatible interactions between the $X$. campestris pv. campestris isolates and wallflower, stock, and candytuft cultivars, but small atypical lesions were occasionally observed. Radish cultivars gave variable reactions with isolates of races 2,3 , and 5. Generally, the isolate of race 2 was only weakly pathogenic even on cv. Wirosa F1, and gave variable responses on radish and wallflower. Two of the race 5 isolates, 3880 and 3883 (previously included in pvs. aberrans and raphani), probably are not sufficiently distinct from $X$. campestris pv. campestris to warrant the status of distinct pathovars.

$X$. campestris isolates from wallflower, stock, and candytuft showed clear evidence of specificity to their host of origin. These isolates were not aggressive on the $X$. campestris pv. campestris susceptible control cv. Wirosa F1. Isolates from wallflower were aggressive on wallflower, but nonpathogenic or weakly pathogenic on other ornamental species. Isolates from stock were very aggressive on stock causing systemic infections and defoliation. The single isolate from candytuft was the only aggressive isolate on candytuft. The isolate from horseradish was only very weakly pathogenic on its host, causing some small lesions and darkening of veins, and nonpathogenic on other hosts.

New differential series and gene-for-gene model. The improved differential series is shown in Table 7, together with a postulated gene-for-gene model to explain the relationship between races and cultivars. Several hypotheses for the allocation of paired resistance (R) and avirulence (A) genes were considered. The model presented is the simplest hypothesis involving the smallest number of genes (four gene pairs) necessary to explain the observed interactions. In this hypothesis, where the pattern of reaction of differential accessions was similar, gene homology was assumed but not tested. A more complex model would be necessary if the differentials Just Right Turnip, Cobra line 14R, and Seven Top Turnip have different genes conferring resistance to race 4, and if PI 199947 and Florida Broad Leaf Mustard have different genes conferring resistance to race 1 .

\section{DISCUSSION}

Races. The identification of races within $X$. campestris pv. campestris by Kamoun et al. (18) (Table 3) was confirmed in the

TABLE 3. Initial differentiation of Xanthomonas campestris pv. campestris into five races ${ }^{\mathrm{a}}$

\begin{tabular}{llllllll}
\hline & \multicolumn{7}{c}{ Races } \\
\cline { 2 - 6 } Differential cultivars & 0 & 1 & 2 & 3 & 4 \\
\hline Wirosa F1 (Brassica oleracea) & + & + & & + & + & + \\
Just Right Hybrid Turnip, & & & & & & \\
$\quad$ Tokyo Cross Hybrid Turnip (Brassica rapa) & + & & + & + & - & - \\
Seven Top Turnip (Brassica rapa) & + & + & & + & + & - \\
Florida Broad Leaf Mustard (Brassica juncea) & & + & - & & + & - & - \\
\hline
\end{tabular}

a Adapted from Kamoun et al. (18); + compatible interaction (susceptibility); - indicates incompatible interaction (resistance).

TABLE 2. Brassica spp. accessions used for race typing the isolates

\begin{tabular}{|c|c|c|c|c|}
\hline Cultivar or accession & Species / variety & Type & Origin & Reaction \\
\hline \multicolumn{5}{|l|}{ Used in initial assays } \\
\hline Wirosa $\mathrm{F} 1^{\mathrm{a}}$ & B. oleracea var. sabauda & Hybrid & Bejo Zaden NV., Netherlands & Susceptible (control) \\
\hline Marathon F1 & B. oleracea var. italica & Hybrid & E.W. King \& Co. Ltd, UK & Susceptible \\
\hline PI 436606 & B. oleracea var. capitata & Open pollinated & USDA; ex. China & $\begin{array}{l}\text { Variable partial resistance to races } \\
\quad 1,2,3,5,6\end{array}$ \\
\hline Green Globe Turnip (HRI 3437) & B. rapa var. rapifera & Open pollinated & HRI Genetic Resources Unit, UK & Variable resistance to race 4 \\
\hline Just Right Hybrid Turnip ${ }^{a}$ & B. rapa var. rapifera & Hybrid & Otis S. Twilley Seed Co., US & Resistance to race 4 \\
\hline Tokyo Cross Hybrid Turnip & B. rapa var. rapifera & Hybrid & Otis S. Twilley Seed Co., US & Resistance to race 4 \\
\hline Seven Top Turnip ${ }^{a}$ & B. rapa var. rapifera & Open pollinated & Otis S. Twilley Seed Co., US & $\begin{array}{l}\text { Resistance to race } 2 \text {; variable } \\
\text { resistance to race } 4\end{array}$ \\
\hline Florida Broad Leaf Mustard ${ }^{\mathrm{a}}$ & B. juncea & Open pollinated & Otis S. Twilley Seed Co., US & Resistance to races 1,3 , and 4 \\
\hline CrGC5 (rapid cycling) & B. napus var. rapifera & Open pollinated & Crucifer Genetics Cooperative, US & Partial resistance to race 4 \\
\hline Cobra (oilseed rape) & B. napus var. oleifera & Open pollinated & Twyfords, UK & Variable resistance to race 4 \\
\hline English Giant (fodder rape) & B. napus var. oleifera & Open pollinated & Charles Sharpe and Company, UK & Variable resistance to race 4 \\
\hline Capricorn (oilseed rape) & B. napus var. oleifera & Open pollinated & Plant Breeding Institute, UK & Susceptible \\
\hline \multicolumn{5}{|l|}{ Added to the differential series } \\
\hline Miracle $\mathrm{F} 1^{\mathrm{a}}$ & B. oleracea var. botrytis & Hybrid & Bejo Zaden NV., Netherlands & Resistance to race 3 \\
\hline Selection of PI $199947^{a}$ & B. carinata & Open pollinated & USDA; ex. Ethiopia & Resistance to races 1,3 , and 4 \\
\hline Line $14 \mathrm{R}$ of Cobra ${ }^{\mathrm{a}}$ & B. napus var. oleifera & Self pollinated & This study & Resistance to race 4 \\
\hline
\end{tabular}

a Accessions included in the new differential series. 
present study with the exception of race 3 . The differentiation of Kamoun's races 3 and 4 depended on the reaction of $B$. rapa cv. Seven Top Turnip. So far, we have found no isolate that conforms to the expected differential reactions of this race. The single isolate (2D513; HRI 6312A) used by Kamoun et al. (18) gave a similar response to an isolate of race 4 in our tests. These tests also showed that cv. Seven Top Turnip was a genetic mixture giving variable reactions to race 4 . Therefore, the uncertainty over the separation of race 3 may have been due to the variable response of cv. Seven Top Turnip. The designation of three races of Kamoun et al. (18) was retained (races 1, 2, and 4) in the new model. Race 0 was redesignated as race 6 . This change in designation was mainly to avoid the implication that race 0 isolates, which were pathogenic to all Brassica accessions in the differential series, lacked avirulence genes. As this cannot be proven, and because we have recently identified Brassica accessions resistant to this race (J. D. Taylor et al., unpublished data), it was considered advisable to avoid the "race 0" designation.

Our results indicate that the original race 1 of Kamoun et al. (18) can be divided into at least three races $(1,3$, and 5) based on the reactions of two $B$. oleracea accessions (cv. Miracle F1 and a doubled haploid line derived from cv. Böhmerwaldkohl) and an accession of B. carinata (PI 199947). Kamoun et al. (18) commented on the considerable variation in virulence among isolates they designated as race 1 . Ignatov et al. (14) separated race 1 isolates into two races, which they designated 1 and 5. Race 3 in our model (a rare race) probably corresponded to Ignatov's race 1. We decided to reserve the race 1 designation for the most common race. Thus the NCPPB type strain of $X$. campestris pv. campestris was included in race 3 . Other authors have noted that this strain caused blight symptoms $(1,6)$ and in this respect is not typical of the majority of $X$. campestris pv. campestris isolates. In our experience blight-like symptoms (dark necrotic lesions with limited chlorosis) were more common in B. oleracea accessions inoculated with isolates of races 5 and 6 . The ability to elicit blight symptoms may be under genetic control (6), but may also be influenced by environmental conditions, especially temperature. Two isolates classified in this study as race 5 of $X$. campestris pv. campestris were the NCPPB type strains of $X$. campestris pv. aberrans and $X$. campestris pv. raphani. Since these isolates show only small pathogenic differences from other $X$. campestris pv. campestris isolates, their original pathovar status may be unwarranted. Vauterin et al. (31) questioned the relevance of these two pathovar designations. The single isolate that represents race 2 (HRI 3849A) appears to differ from all other isolates of $X$.

TABLE 4. Frequency of occurrence and host of origin of Xanthomonas campestris pv. campestris races among $102 \mathrm{UK}$ isolates

\begin{tabular}{|c|c|c|c|}
\hline \multicolumn{2}{|c|}{ Race designation } & \multirow[b]{2}{*}{ Host of origin (number of isolates) } & \multirow[b]{2}{*}{ Isolates } \\
\hline $\begin{array}{l}\text { This } \\
\text { study }\end{array}$ & $\begin{array}{l}\text { Kamoun } \\
\text { et al. (18) }\end{array}$ & & \\
\hline 1 & 1 & $\begin{array}{l}\text { Brassica oleracea } \text { var. botrytis }(40) \\
\text { Brassica oleracea } \text { var. capitata } \times \text { sabauda }(14) \\
\text { Brassica oleracea } \text { var. sabauda (3) } \\
\text { Brassica oleracea } \text { var. capitata }(6) \\
\text { Brassica oleracea } \text { var. gemmifera }(1) \\
\text { Brassica oleracea } \text { var. unknown (1) } \\
\text { Sinapis arvensis } \text { and other weeds (5) }\end{array}$ & $70^{\mathrm{a}}$ \\
\hline 3 & 1 & Brassica oleracea var. gemmifera (1) & 1 \\
\hline 4 & 4 & $\begin{array}{l}\text { Brassica oleracea } \text { var. botrytis }(28) \\
\text { Brassica oleracea } \text { var. capitata } \times \text { sabauda }(1) \\
\text { Brassica oleracea } \text { var. capitata }(1) \\
\text { Brassica oleracea } \text { var. gemmifera }(1)\end{array}$ & 31 \\
\hline
\end{tabular}

${ }^{a}$ Thirty-eight of these isolates were not tested on the three new differentials (Miracle F1, PI 199947, and Cobra 14R); these isolates are most probably race 1. campestris pv. campestris. This isolate has been used extensively in molecular studies of resistance in Arabidopsis thaliana (5,17, 29). It is unfortunate that important studies have been made with an isolate that appears to be both atypical and rare.

Distribution of races. Race 1 appears to be currently the most common race in $B$. oleracea crops in the United Kingdom. Worldwide, races 1 and 4 are predominant. Races 2, 3, 5, and 6 were rare in the collection tested. Race 2 and race 6 (previously designated race 0 ) were also absent in a collection of isolates from Japan and Russia (13). The low frequency of race 3 may be due to the extensive use of cultivars that are resistant to this race (J. D. Taylor et al., unpublished data). This may not always have been the case, since the NCPPB type strain of $X$. campestris pv. campestris, isolated in 1957 , is race 3 . Race 5 was not found among European isolates. Race 6 was not found among UK isolates, but this may have been due to the preponderance of isolates from B. oleracea. In Portugal, race 6 is common in turnip (32). Monitoring the frequency and distribution of races worldwide is essential to the development of effective strategies for resistance breeding.

The three isolates from cruciferous weeds that were examined in this study were of the same race as present in associated $B$. oleracea crops. It is suggested that the infection originated from the crops, because the crops frequently showed uniform infections and the weeds were sparse. Smith (28) also considered that the cultivated plants were more likely to be a source of inoculum for weeds than vice versa. Dane and Shaw (7) observed that the dispersal of a marked strain of $X$. campestris pv. campestris from cabbages to weeds was frequent.

Pathovars. A pathovar is defined as "a strain or set of strains with the same or similar characteristics, differentiated at the infrasubspecific level from other strains of the same species or subspecies on the basis of distinctive pathogenicity to one or more plant hosts" (8). On the basis of host specificity, the isolates examined in this study appear to represent four distinct pathovars of $X$. campestris. Most of the X. campestris pv. campestris isolates obtained in this study were pathogenic to a number of Brassica accessions, including cv. Wirosa F1, confirming their identification as $X$. campestris pv. campestris. The only isolates that were clearly different from $X$. campestris pv. campestris in respect of host range were those that had originated from wallflower, stock, and candytuft. Of the recognized names, only $X$. campestris pv. incanae appears to be appropriate for the isolates that are pathogenic on stock. Our results are in agreement with the descriptions of Kendrick (19) and Wilson (37). The isolates from wallflower should not be included in $X$. campestris pv. incanae as suggested by Bradbury (3), nor in X. campestris pv. campestris, because they were clearly specific in their pathogenicity to wallflower and were not pathogenic on the differential series of Brassica spp. A single isolate from candytuft listed as X. campestris pv. armoraciae was pathogenic to candytuft but not to horse-

TABLE 5. Frequency of occurrence and geographical distribution of Xanthomonas campestris pv. campestris races among 42 non-UK isolates

\begin{tabular}{|c|c|c|c|}
\hline \multicolumn{2}{|c|}{ Race designation } & \multirow[b]{2}{*}{ Country of origin (number of isolates) } & \multirow[b]{2}{*}{ Isolates } \\
\hline $\begin{array}{l}\text { This } \\
\text { study }\end{array}$ & $\begin{array}{l}\text { Kamoun } \\
\text { et al. (18) }\end{array}$ & & \\
\hline 1 & 1 & $\begin{array}{l}\text { France (2), Greece (1), Kenya (1), Namibia } \\
\text { (1), Papua New Guinea (1), Portugal (2), } \\
\text { Russia (2), South Africa (4), Thailand } \\
\text { (2), US (2), unknown (1) }\end{array}$ & 19 \\
\hline 2 & 2 & US (1) & 1 \\
\hline 3 & 1 & Greece (1), France (1) & 2 \\
\hline 4 & 4 & $\begin{array}{l}\text { Brazil (2), Italy (4), Kenya (1), Portugal } \\
\quad \text { (2), South Africa (3), Spain (1), US (2) }\end{array}$ & 15 \\
\hline 5 & 1 & Australia (1), Canada (1), US (1) & 3 \\
\hline 6 & 0 & Portugal (2) & 2 \\
\hline
\end{tabular}


radish. These isolates from wallflower and candytuft are clearly distinct in their host range and may warrant the creation of new pathovars. $X$. campestris pv. armoraciae was described as the causal agent of a nonvascular leaf spot disease of horseradish (23). Later, leaf spots on cauliflower, cabbage, turnip, and radish were also attributed to this pathovar $(6,26,27)$. One isolate received under this pathovar designation caused symptoms of $X$. campestris pv. campestris in some of the Brassica differentials and had probably been misidentified. The single isolate from horseradish tested gave only a weakly pathogenic reaction on horseradish. We did not observe leaf spots in our tests, but the inoculation method used (leaf clipping) might not be the most appropriate for symptom development. Spray inoculating might be a better method to produce leaf spots. We were unable to substantiate or refute the existence of $X$. campestris pv. armoraciae.

Some of the isolates that were either nonpathogenic or very weakly pathogenic had been obtained from other researchers and official collections. Neither the pathovar nor the race of these isolates could be determined. Loss of pathogenicity may have been due to poor maintenance conditions, and preserving isolates in an appropriate way is important for their long-term survival.

Differential series and gene-for-gene model. A modified and improved differential series was established in this study. This series has some disadvantages: it includes some cultivars, such as cv. Seven Top Turnip, which give variable reactions and were shown to be genetic mixtures. It also includes F1 hybrids that give uniform reactions, but their availability is problematic, depending on their commercial success. It is important, therefore, that the differential series is improved through the development of uni- form lines, either through several generations of self-pollination or preferably through microspore or anther culture. If uniform lines of differential cultivars were maintained in a germplasm bank, their availability for research and for resistance breeding would be ensured.

The proposed gene-for-gene model shown in Table 7 is based on the interaction of at least four matching gene pairs. The genes that confer resistance to the most important races (1 and 4) were designated R1 and R4. The gene R1, present in B. carinata accession PI 199947 and possibly in B. juncea cv. Florida Broad Leaf Mustard, confers resistance to races 1 and 3 (with A1) and possibly to race 4 if this race also has $\mathrm{A} 1$. This gene could have originated in the B genome of $B$. nigra from which these two species are derived. The reaction of $B$. rapa cv. Just Right Turnip and B. napus cv. Cobra line $14 \mathrm{R}$ is explained by the interaction of $\mathrm{R} 4$ with the avirulence gene A4 present in race 4 . This gene could have originated in the A genome of B. rapa. R2, present in $B$. rapa cv. Seven Top Turnip, confers resistance to the single isolate of race 2. R3, present in B. oleracea cv. Miracle F1, confers resistance to race 3 and possibly to races 2 and 5, which have A3. Cultivar Florida Broad Leaf Mustard might have another gene that could explain the partial resistance to isolates of race 5. The model allows for the possible inclusion of additional gene pairs if new races and differentials are identified. In general, the model was constructed in a way that reflects the origin of the allotetraploid species of Brassica (30): R1 originates from the B genome, $\mathrm{R} 3$ from the $\mathrm{C}$ genome, and $\mathrm{R} 4$ from the A genome.

The postulated gene-for-gene relationship provides a basis for understanding the interactions of races and cultivars, but to be

TABLE 6. Host range of Xanthomonas campestris pathovars from cruciferous hosts ${ }^{\mathrm{a}}$

\begin{tabular}{|c|c|c|c|c|c|c|c|c|}
\hline \multirow[b]{2}{*}{ HRI isolate } & \multirow[b]{2}{*}{ Original designation } & \multirow[b]{2}{*}{ Host of origin } & \multicolumn{6}{|c|}{ Pathogenicity to ${ }^{\mathrm{b}}$} \\
\hline & & & Savoy cabbage & Radish & Wallflower & Stock & Candytuft & Horseradish \\
\hline $3811(1)$ & X. campestris pv. campestris & B. oleracea & + & + & - & - & - & - \\
\hline 3849A (2) & X. campestris pv. campestris & B. oleracea & + & $+/-$ & $+/-$ & - & - & - \\
\hline $5212(3)$ & X. campestris pv. campestris & B. oleracea & + & $+/-$ & - & - & - & - \\
\hline $1279 \mathrm{~A}(4)$ & X. campestris pv. campestris & B. oleracea & + & + & - & - & - & - \\
\hline $6382(5)$ & X. campestris pv. campestris & B. rapa & + & $+/-$ & - & - & - & nt \\
\hline $6181(6)$ & $X$. campestris pv. campestris & B. rapa & + & + & - & - & - & - \\
\hline $3880(5)$ & X. campestris pv. aberrans & B. oleracea & + & $+1-$ & - & - & - & - \\
\hline $3883(5)$ & $X$. campestris pv. raphani & Raphanus sativus & + & $+/-$ & - & - & - & nt \\
\hline 3777A, 5219A & $X$. campestris pv. campestris & Cheiranthus cheiri & - & - & + & - & - & nt \\
\hline 6377,6378 & $X$. campestris pv. incanae & Matthiola $\mathrm{sp}$. & - & - & - & + & - & nt \\
\hline 6375 & X. campestris pv. armoraciae & Iberis sp. & - & $+/-$ & - & - & + & - \\
\hline 6376 & X. campestris pv. armoraciae & Armoracia rusticana & - & - & - & - & - & $(+)$ \\
\hline
\end{tabular}

${ }^{\mathrm{a}}+$, compatible interaction (susceptibility); -, incompatible interaction (resistance); (+), weakly pathogenic; +/-, variable reaction between and within cultivars; nt, not tested.

b Savoy cabbage, Brassica oleracea ); radish, Raphanus sativus; wallflower, Cheiranthus chieri; candytuft, Iberis sp.; stock, Matthiola incana; and horseradish, Armoracia rusticana.

TABLE 7. Postulated gene-for-gene model to explain the relationship between Brassica cultivars and races of Xanthomonas campestris pv. campestris ${ }^{\mathrm{a}}$

\begin{tabular}{|c|c|c|c|c|c|c|c|c|c|c|c|}
\hline & & & & & & & & Avir & gene & & \\
\hline & & & & & & 1 & 2 & 3 & 4 & 5 & 6 \\
\hline & & & & & & A1 & $\ldots$ & A1 & A1? & $\ldots$ & $\ldots$ \\
\hline & & & & & & $\ldots$ & A 2 & $\ldots$ & $\ldots$ & $\cdots$ & $\ldots$ \\
\hline & & & & & & $\ldots$ & A3 & A3 & $\ldots$ & A3 & $\ldots$ \\
\hline & & & & & & $\ldots$ & $\ldots$ & $\ldots$ & A4 & $\ldots$ & $\ldots$ \\
\hline & & & & & & $\cdots$ & $\cdots$ & $\cdots$ & $\cdots$ & $\ldots$ & $\cdots$ \\
\hline Differential cultivars or accessions & & & tance & & & $\ldots$ & $\ldots$ & $\ldots$ & $\ldots$ & $?$ & $\ldots$ \\
\hline Wirosa F1 (B. oleracea) & $\ldots$ & $\ldots$ & $\ldots$ & $\ldots$ & $\ldots$ & + & + & + & + & + & + \\
\hline Just Right Hybrid Turnip (B. rapa), & & & & & & & & & & & \\
\hline Line $14 \mathrm{R}$ of Cobra (B. napus) & $\ldots$ & $\ldots$ & $\ldots$ & R4 & $\ldots$ & + & + & + & - & + & + \\
\hline Seven Top Turnip (B. rapa) & $\ldots$ & $\mathrm{R} 2$ & $\ldots$ & $\mathrm{R} 4$ & $\ldots$ & + & - & + & - & + & + \\
\hline PI 199947 (B. carinata) & $\mathrm{R} 1$ & $\ldots$ & $\ldots$ & $\mathrm{R} 4$ ? & $\ldots$ & - & + & - & - & + & + \\
\hline Florida Broad Leaf Mustard (B. juncea) & $\mathrm{R} 1$ & $\ldots$ & $\ldots$ & $\mathrm{R} 4 ?$ & $?$ & - & + & - & - & $(+)$ & + \\
\hline Miracle F1 (B. oleracea) & $\ldots$ & $\ldots$ & R3 & $\ldots$ & $\ldots$ & + & - & - & + & - & + \\
\hline
\end{tabular}

$\mathrm{a}+=$ compatible interaction (susceptibility); $-=$ incompatible interaction (resistance); and $(+)=$ weakly pathogenic. 
fully validated the model needs to be supported by genetic and molecular data from both the host and the pathogen. In the case of the host, results of crosses made recently to establish the inheritance of resistance to some of the races indicate that R1, R3, and R4 are single dominant genes (J. G. Vicente, J. G. Taylor, D. J. Lydiate, I. A. P. Parkin, A. G. Sharpe, and G. J. King, unpublished data).

The model, and more especially the availability, of defined race type strains should assist in the selection of resistant material for breeding programs. Disease resistance screening must be done with isolates representing the full pathogenic variation of $X$. campestris pv. campestris and especially the major races, 1 and 4. In addition, isolates of race 6 can be used to detect potential racenonspecific resistance. Future breeding programs aiming to achieve durable resistance will need to combine race-specific resistance genes (R1 and R4) that confer strong resistance to the most important races of the pathogen. If possible, they will also need race-nonspecific genes that could confer quantitative resistance to all known races.

\section{ACKNOWLEDGMENTS}

This work was supported by the Ministry of Agriculture, Fisheries and Food (MAFF) and the Biotechnology and Biological Sciences Research Council (BBSRC). J. Vicente was supported by a grant from PRAXIS XXI (ref. BD/3780/94). We thank the following researchers for sending isolates: M. J. Daniels (Sainsbury Laboratory, UK), S. Redstone (University of Plymouth, Devon, UK), A. Ignatov (Institute of Vegetable Breeding and Seed Production, Moscow, Russia), D. Silué (Bretagne Biotechnologie Vegetale, France), V. Catara (Istituto di Patologia Vegetale, University of Catania, Italy), M. Scortichini (Istituto Sperimentale per la Patologia Vegetale, Rome, Italy), A. A. J. M. Franken (CPRO-DLO, Netherlands), C. Grimm (Institute of Botany and Botanical Garden, University of Vienna, Austria), C. I. Kado (University of California, Davis), K. van't Hoenderdal (Nickerson-Zwaan, Netherlands), and J. Serfontein (Plant Protection Research Institute, Agricultural Research Council, South Africa).

\section{LITERATURE CITED}

1. Alvarez, A. M., Benedict, A. A., Mizumoto, C. Y., Hunter, J. E., and Gabriel, D. W. 1994. Serological, pathological, and genetic diversity among strains of Xanthomonas campestris infecting crucifers. Phytopathology 84:1449-1457.

2. Bain, D. C. 1952. Reaction of Brassica seedlings to black rot. Phytopathology 42:497-500.

3. Bradbury, J. F. 1986. Guide to Plant Pathogenic Bacteria. CAB International, Wallingford, UK.

4. Brinkerhoff, L. A. 1970. Variation in Xanthomonas malvacearum and its relation to control. Ann. Rev. Phytopathol. 8:85-110.

5. Buell, C. R., and Somerville, S. C. 1997. Use of Arabidopsis recombinant inbred lines reveals a monogenic and a novel digenic resistance mechanism to Xanthomonas campestris pv. campestris. Plant J. 12:21-29.

6. Chen, J., Roberts, P. D., and Gabriel, D. W. 1994. Effects of a virulence locus from Xanthomonas campestris $528^{\mathrm{T}}$ on pathovar status and ability to elicit blight symptoms on crucifers. Phytopathology 84:1458-1465.

7. Dane, F., and Shaw, J. J. 1996. Survival and persistence of bioluminescent Xanthomonas campestris pv. campestris on host and nonhost plants in the field environment. J. Appl. Bacteriol. 80:73-80.

8. Dye, D. W., Bradbury, J. F., Goto, M., Hayward, A. C., Lelliott, R. A., and Schroth, M. N. 1980. International standards for naming pathovars of phytopathogenic bacteria and a list of pathovar names and pathotype strains. Rev. Plant Pathol. 59:153-168.

9. Feltham, R. K. A., Power, A. K., Pell, P. A., and Sneath, P. H. A. 1978. A simple method for the storage of bacteria at $-76^{\circ} \mathrm{C}$. J. Appl. Bacteriol. 44:313-316.

10. Guo, H., Dickson, M. H., and Hunter, J. E. 1991. Brassica napus sources of resistance to black rot of crucifers and inheritance of resistance. HortScience 26:1545-1547.
11. Hunter, J. E., Dickson, M. H., and Ludwig, J. 1987. Source of resistance to black rot of cabbage expressed in seedlings and adult plants. Plant Dis. 71:263-266.

12. Hunter, R. E., Brinkerhoff, L. A., and Bird, L. S. 1968. The development of a set of upland cotton lines for differentiating races of Xanthomonas malvacearum. Phytopathology 58:830-832.

13. Ignatov, A., Hida K., and Kuginuki Y. 1998. Black rot of crucifers and sources of resistance in Brassica crops. Jpn. Agric. Res. Q. 32:167-172.

14. Ignatov, A., Kuginuki, Y., and Hida, K. 1998. Race-specific reaction of resistance to black rot in Brassica oleracea. Eur. J. Plant Pathol. 104: 821-827.

15. Ignatov, A., Vicente, J. G., Conway, J., Roberts, S. J., and Taylor, J. D. 1997. Identification of Xanthomonas campestris pv. campestris races and sources of resistance. Page 215 in: ISHS Symp./10th. Crucifer Genet. Workshop.

16. Jones, J. B., Stall, R. E., and Bouzar, H. 1998. Diversity among Xanthomonads pathogenic on pepper and tomato. Annu. Rev. Phytopathol. 36:41-58.

17. Kamoun, S., and Kado, C. I. 1990. A plant inducible gene of Xanthomonas campestris pv. campestris encodes an exocellular component required for growth in the host and hypersensitivity on non hosts. J. Bacteriol. 172:5165-5172.

18. Kamoun, S., Kamdar, H. V., Tola, E., and Kado, C. I. 1992. Incompatible interactions between crucifers and Xanthomonas campestris involve a vascular hypersensitive response: Role of the hrpX locus. Mol. PlantMicrobe Interact. 5:22-23.

19. Kendrick, J. B. 1938. A seed-borne bacterial disease of garden stocks, Matthiola incana. (Abstr.) Phytopathology 28:12.

20. King, E. O., Ward, M. K., and Raney, D. R. 1954. Two simple media for the demonstration of pyrocanin and fluorescin. J. Lab. Clin. Med. 44: 301-307.

21. Leyns, F., De Cleene, M., Swings, J. G., and De Ley, F. 1984. The host range of the genus Xanthomonas. Bot. Rev. 50:308-356.

22. Lyons, N. F., and Taylor, J. D. 1990. Serological detection and identification of bacteria from plants by the conjugated Staphylococcus aureus slide agglutination test. Plant Pathol. 39:584-590.

23. McCulloch, L. 1929. A bacterial leaf spot of horse-radish caused by Bacterium campestris var. armoraciae, n. var. J. Agric. Res. 38:269-287.

24. Mew, T. W. 1987. Current status and future prospects of research on bacterial blight of rice. Annu. Rev. Phytopathol. 25:359-382.

25. Opio, A. F., Allen, D. J., and Teri, J. M. 1996. Pathogenic variation in Xanthomonas campestris pv. phaseoli, the causal agent of common bacterial blight in Phaseolus beans. Plant Pathol. 45:1126-1133.

26. Rao, Y. P., and Srivastava, D. N. 1962. A bacterial leaf spot disease of crucifers. Indian Phytopathol. 15:238-242.

27. Sahin, F., and Miller, S. A. 1997. A new pathotype of Xanthomonas campestris pv. armoraciae that causes bacterial leaf spot of radish. Plant Dis. 81:1334.

28. Smith, E. F. 1898. The black rot of the cabbage. U.S. Dept. Agric. Farmer's Bull. 68:1-21.

29. Tsuji, J., Somerville, S. C., and Hammerschmidt, R. 1991. Identification of a gene in Arabidopsis thaliana that controls resistance to Xanthomonas campestris pv. campestris. Physiol. Mol. Plant Pathol. 38:57-65.

30. N. 1935. Genome analysis in Brassica with special reference to the experimental formation of B. napus and peculiar mode of fertilization. Jpn. J. Bot. 7:389-452.

31. Vauterin, L., Hoste, B., Kesters, K., and Swings, J. 1995. Reclassification of Xanthomonas. Int. J. Syst. Bacteriol. 45:472-489.

32. Vicente, J. G., Dias, J. S., and Taylor, J. D. 1997. Occurrence and distribution of Xanthomonas campestris pv. campestris races in Portugal. Page 214 in: ISHS Symp./10th. Crucifer Genet. Workshop.

33. Vicente, J. G., Ignatov, A., Conway, J., Roberts, S. J., and Taylor, J. D. 1998. Development of an improved Brassica differential series for the identification of races of Xanthomonas campestris pv. campestris. Page 2.2.71 in: Int. Cong. Plant Pathol., 7th.

34. Westman, A. L., Kresovich, S., and Dickson, M. H. 1999. Regional variation in Brassica nigra and other weedy crucifers for disease reaction to Alternaria brassicicola and Xanthomonas campestris pv. campestris. Euphytica 106:253-259.

35. Williams, P. H. 1980. Black rot: A continuing threat to world crucifers. Plant Dis. 64:736-742.

36. Williams, P. H., Staub, T., and Sutton, J. C. 1972. Inheritance of resistance in cabbage to black rot. Phytopathology 62:247-252.

37. Wilson, R. D. 1942. Black rot of garden stocks. Agric. Gaz. 1:33-35. 